\title{
(-)-Asarinin from the Roots of Asarum sieboldii Induces Apoptotic Cell Death via Caspase Activation in Human Ovarian Cancer Cells
}

\author{
Miran Jeong ${ }^{1,+}$, Hye Mi Kim ${ }^{1,+}$, Jin Su Lee ${ }^{1,2}$, Jung-Hye Choi ${ }^{1,2, *}$ and Dae Sik Jang ${ }^{1,2, *}$ \\ 1 College of Pharmacy, Kyung Hee University, Seoul 02447, Korea; jeongmiran@hanmail.net (M.J.); \\ hyemi586@gmail.com (H.M.K.); lee2649318@naver.com (J.S.L.) \\ 2 Department of Life \& Nanopharmaceutical Sciences, Kyung Hee University, Seoul 02447, Korea \\ * Correspondence: jchoi@khu.ac.kr (J.-H.C.); dsjang@khu.ac.kr (D.S.J.); Tel.: +82-2-961-2172 (J.-H.C.); \\ $+82-2-961-0719$ (D.S.J.) \\ + These authors contributed equally to this work.
}

Received: 30 May 2018; Accepted: 24 July 2018; Published: 25 July 2018

\begin{abstract}
Two tetrahydrofurofurano lignans (1 and 2), four phenylpropanoids (3-6), and two alkamides ( 7 and 8$)$ were isolated from the EtOAc-soluble fraction of the roots of Asarum sieboldii. The chemical structures of the isolates were identified by analysis of spectroscopic data measurements, and by a comparison of their data with published values. The isolates (1, 2, 4-8) were evaluated for their cytotoxicity against human ovarian cancer cells (A2780 and SKOV3) and immortalized ovarian surface epithelial cells (IOSE80PC) using a MTT (3-(4,5-dimethylthiazol-2-yl)-2,5-diphenyl-tetrazolium bromide) assay. Of the isolates, (-)-asarinin (1) exhibited the most potent cytotoxicity to both A2780 and SKOV3 cells. A propidium iodide/annexin V-fluorescein isothiocyanate (V-FITC) double staining assay showed that (-)-asarinin (1) induces apoptotic cell death in ovarian cancer cells. In addition, (-)-asarinin (1) increased the activation of caspase- 3 , caspase- 8 , and caspase- 9 in ovarian cancer cells. Pretreatment with caspase inhibitors attenuated the cell death induced by (-)-asarinin (1). In conclusion, our findings show that (-)-asarinin (1) from the roots of $A$. sieboldii may induce caspase-dependent apoptotic cell death in human cancer cells.
\end{abstract}

Keywords: Asarum sieboldii; (-)-asarinin; cytotoxicity; ovarian cancer cells; apoptosis; caspase

\section{Introduction}

Asarum sieboldii Miq. (Aristolochiaceae) is a herbal plant that is widely distributed in Korea, China, and Japan. In traditional medicine, the roots of $A$. sieboldii are used as treatment for all types of colds, fever, chills, headaches, acute toothaches, sinusitis, cough, and dyspnoea, due to retention of phlegm, pharyngitis, chronic gastritis, and rheumatoid arthritis [1,2]. It has been demonstrated that $A$. sieboldii has a broad range of biological activity, such as anti-allergic [3], antitussive [4], anti-inflammatory [5], anti-nociceptive [6], anti-fungal [7,8], neuroprotective [9], and anticancer activity [10,11]. Previous phytochemical investigations on the roots of $A$. sieboldii resulted in the isolation of essential oils [12, 13], alkamides [5,14], lignans [5,14], and alkaloids [15,16]. A 70\% EtOH extract from Asiasari radix induced apoptosis preceded by a tight cell cycle arrest in the G2/M phase, suggesting that the extract prevented the growth of HCT-116 human colon cancer cells. The extract increased the expression of Bax/Bcl-2 and p53, and activated caspases, including Caspase-9 and Caspase-8 [10]. In addition, Asiasari radix extract significantly enhanced the sensitivity of HeLa cells to paclitaxel [17]. Moreover, Park et al. have demonstrated that the EtOAc-soluble fraction of Asiasari radix exhibits cytotoxic activity against human cancer cell lines such as A549 (human lung cancer), SKOV3 (human ovarian 
cancer), and SKMEL-2 (human melanoma) [11]. As part of an our ongoing project to search for novel, plant-derived anti-cancer agents [18], we found that the EtOAc-soluble fraction of the 70\% EtOH extract of $A$. sieboldii roots exhibited significant cytotoxicity in the human ovarian cancer cells A2780 and SKOV3. Fractionation of the active EtOAc-soluble fraction resulted in the isolation and identification of eight known compounds consisting of tetrahydrofurofurano lignans (1 and 2), phenylpropanoids (3-6), and alkamides (7 and 8). The structures of the isolates were determined by spectroscopic analyses, including ${ }^{1} \mathrm{H}-\mathrm{NMR},{ }^{13} \mathrm{C}-\mathrm{NMR}, 2 \mathrm{D}-\mathrm{NMR}$, and MS spectra, and via a comparison of the data with published values. The isolates $(\mathbf{1}, \mathbf{2}, \mathbf{4}-\mathbf{8})$ were evaluated for their cytotoxicity against human ovarian cancer cells (A2780 and SKOV3) and immortalized ovarian surface epithelium cells (IOSE80PC), using MTT (3-(4,5-dimethylthiazol-2-yl)-2,5-diphenyl-tetrazolium bromide) assays. Of the isolates, a tetrahydrofurofurano lignin (-)-asarinin (1), which displayed potent cytotoxicity against both A2780 and SKOV3 cells, was investigated for the molecular mechanism of its cytotoxic activity. Here, we describe the isolation and identification of the isolates (1-8) from the roots of $A$. sieboldii, as well as their cytotoxicity to human ovarian cancer cells. This paper also deals with a mechanism study for cytotoxicity of (-)-asarinin (1) in human cancer cells.

\section{Results}

\subsection{Cytotoxicity of the Extract and Solvent Fractions against Human Ovarian Cancer Cells}

The $70 \% \mathrm{EtOH}$ extract of the roots of $A$. sieboldii and two solvent partitions (EtOAc- and water-soluble fractions) from the $70 \% \mathrm{EtOH}$ extract were investigated for their cytotoxicity against human ovarian cancer cells (A2780 and SKOV3) using MTT assays (Table 1). The 70\% EtOH extract showed a significant cytotoxicity against A2780, with an observed $\mathrm{IC}_{50}$ value of $31.5 \pm 16.83 \mu \mathrm{g} / \mathrm{mL}$. Of the solvent partitions, the EtOAc-soluble fraction exhibited more potent cytotoxicity than the water-soluble fraction, against both ovarian cancer cells $\left(\mathrm{IC}_{50}\right.$ values were 19.89 and $118.47 \mu \mathrm{g} / \mathrm{mL}$ in A2780 and SKOV3, respectively). Thus, we attempted to identify the cytotoxic constituents in the EtOAc-soluble fraction. Our data on the EtOAc-soluble fraction were consistent with previous results [11] on the cytotoxic activity of the EtOAc-soluble fraction of Asiasari radix against several human cancer cell lines including SKOV3 cells.

Table 1. Cytotoxicity of the $70 \%$ EtOH extract of $A$. sieboldii roots and its solvent fractions in human ovarian cancer cells A2780 and SKOV3.

\begin{tabular}{ccc}
\hline & \multicolumn{2}{c}{$\mathrm{IC}_{\mathbf{5 0}}(\mu \mathrm{g} / \mathrm{mL}){ }^{*}$} \\
\cline { 2 - 3 } Extract or Fractions & \multicolumn{2}{c}{ Human Ovarian Cancer Cells } \\
\cline { 2 - 3 } & $\mathbf{A 2 7 8 0}$ & SKOV3 \\
\hline 70\% EtOH extract & $31.5 \pm 16.83$ & $>200$ \\
EtOAc fraction & $19.89 \pm 4.20$ & $118.47 \pm 19.78$ \\
Water fraction & $107.20 \pm 15.80$ & $139.30 \pm 29.13$ \\
\hline
\end{tabular}

* The $\mathrm{IC}_{50}$ value is defined as being a concentration that lowers cell viability by $50 \%$. The value shows an average of the results of three independent experiments having similar patterns.

\subsection{Identification of Compounds 1-8 from the Roots of $A$. sieboldii}

Two tetrahydrofurofurano lignans (1 and 2), four phenylpropanoids (3-6), and two alkamides (7 and 8) were isolated from the active EtOAc-soluble fraction of the roots of $A$. sieboldii. The chemical structures of the isolates were identified to be (-)-asarinin (1) [19], (-)-pluviatilol (2) [20], kakuol (3) [21], methylkakuol (4) [21], asaricin (5) [22], methyleugenol (6) [23], (2E,4E,8Z)- $N$-isobutyldeca-2,4,8-trienamide (7) [23], and (2E,4E,8Z,10E/Z)-N-isobutyldodeca-2,4,8,10-tetraenamide (8) [24], by analysis of spectroscopic data $\left({ }^{1} \mathrm{H}-\mathrm{NMR},{ }^{13} \mathrm{C}-\mathrm{NMR}, 2 \mathrm{D}-\mathrm{NMR}\right.$, and MS) measurements, and by a comparison of their data with published values (Figure 1). 
<smiles>c1cc2c(cc1[C@@H]1OC[C@@H]3[C@H](c4ccc5c(c4)OCO5)OC[C@H]13)OCO2</smiles>

1<smiles>COc1cc([C@H]2OC[C@H]3[C@H]2CO[C@H]3c2ccc3c(c2)OCO3)ccc1O</smiles><smiles>C=CCc1ccc(OC)c(OC)c1</smiles>

$3 \mathrm{R}=\mathrm{H}$

$4 \mathrm{R}=\mathrm{CH}_{3}$<smiles>C=CCc1cc2c(cc1OC)OCO2</smiles>

5<smiles>CC=CC=CC=CC(=O)NCC(C)C</smiles>

Figure 1. Compounds 1-8 isolated from the EtOAc-soluble fraction of the roots of $A$. sielboldii.

\subsection{Cytotoxicity of Compounds 1-8 against Human Ovarian Cancer Cells}

To identify compounds with cytotoxic activity against human cancer cells from the A. sieboldii roots, we investigated the effect of the isolates $(\mathbf{1}, \mathbf{2}, \mathbf{4 - 8})$ obtained from the EtOAc-soluble fraction of the roots of $A$. sieboldii in human ovarian cancer cells A2780 and SKOV3. The effects of the isolates were assessed using $\mathrm{IC}_{50}$ values and they are summarized in Table 2. Of these, a tetrahydrofurofurano lignin, (-)-asarinin (1), exhibited the most potent cytotoxicity on both A2780 and SKOV3 cells, with observed $\mathrm{IC}_{50}$ values of $38.45 \pm 2.78$ and $60.87 \pm 5.01 \mu \mathrm{M}$, respectively. Interestingly, $(-)$-asarinin (1) did not show any cytotoxicity against immortalized ovarian surface epithelial IOSE80PC cells, which were used as a normal counterpart of ovarian cancer cells. On the other hand, another lignan (-)-pluviatilol (2) showed a mild cytotoxicity against all the three cells tested (A2780 (IC 50 value of $101.85 \pm 13.55 \mu \mathrm{M})$, SKOV3 $\left(\mathrm{IC}_{50}\right.$ value of $\left.173.82 \pm 9.42 \mu \mathrm{M}\right)$, and IOSE80PC cells $\left(\mathrm{IC}_{50}\right.$ value of $178.92 \pm 3.30 \mu \mathrm{M}))$. An alkamide, $(2 E, 4 E, 8 Z, 10 E / Z)-N$-isobutyldodeca-2,4,8,10-tetraenamide (8), exhibited a mild cytotoxicity only against $\mathrm{A} 2780$ cells $\left(\mathrm{IC}_{50}\right.$ value of $\left.101.20 \pm 10.35 \mu \mathrm{M}\right)$, but not against SKOV3 cells. These results implicate that (-)-asarinin (1), one of major constituents of the roots of $A$. sieboldii, seems to contribute to the cytotoxicity of the EtOAc-soluble fraction against cancer cells. (-)-Sesamin, which is an epimer of asarinin and is also found in this plant [5], exerts cytotoxic activity toward cancer cells and induces apoptosis in vitro [25-28]. An anticancer effect of (-)-sesamin in athymic mice transplanted with human MCF-7 breast cancer cells has also been reported [25]. Furthermore, the dietary supplementation of (-)-sesamin on 7,12-dimethylbenz[a]anthracene (DMBA)-induced breast carcinogenesis led to a significantly reduced appearance of breast cancers, compared to mice that were not supplemented with (-)-sesamin [26]. In contrast, (-)-asarinin (1) has been suggested to have a significant inhibitory effect on EBV-EA activation and preserved the high viability of the Raji cells [29,30]. In addition, (-)-asarinin (1) inhibited DNA synthesis in human leukemia HL-60 cells [31]. However the effect of (-)-asarinin (1) on human solid cancer cell growth and its underlying molecular mechanism have not been reported to date. 
Table 2. Cytotoxicity of compounds 1-8 from the EtOAc-soluble fraction of the roots of A. sieboldii in human ovarian cancer cells (A2780 and SKOV3) and immortalized ovarian surface epithelial cells (IOSE80PC).

\begin{tabular}{|c|c|c|c|}
\hline \multirow{3}{*}{ Compound } & \multicolumn{3}{|r|}{$\mathrm{IC}_{50}(\mu \mathrm{M}) *$} \\
\hline & \multicolumn{2}{|c|}{ Human Ovarian Cancer Cells } & \multirow{2}{*}{$\begin{array}{c}\text { Immortalized Ovarian Surface Epithelial Cells } \\
\text { IOSE80PC }\end{array}$} \\
\hline & A2780 & SKOV3 & \\
\hline 1 & $38.45 \pm 2.78$ & $60.87 \pm 5.01$ & $>200$ \\
\hline 2 & $101.85 \pm 13.55$ & $173.82 \pm 9.42$ & $178.92 \pm 3.30$ \\
\hline 3 & $>200$ & $>200$ & $>200$ \\
\hline 4 & $>200$ & $>200$ & $>200$ \\
\hline 5 & $\mathrm{ND}^{* *}$ & $\mathrm{ND} * *$ & $\mathrm{ND}^{* *}$ \\
\hline 6 & $>200$ & $>200$ & $>200$ \\
\hline 7 & $>200$ & $>200$ & $>200$ \\
\hline 8 & $101.20 \pm 10.35$ & $>200$ & $>200$ \\
\hline Cisplatin *** & $8.77 \pm 0.48$ & $24.18 \pm 0.28$ & $45.62 \pm 0.30$ \\
\hline
\end{tabular}

${ }^{*} \mathrm{IC}_{50}$ value is defined as the concentration that results in a $50 \%$ decrease in the proliferation of the cells. The values represent the means of the results from three independent experiments with similar patterns. ${ }^{* *}$ Not determined since the amount of available compound was insufficient. ${ }^{* * *}$ Cisplatin was used as an assay positive control.

\section{4. (-)-Asarinin (1)-Induced Apoptotic Cell Death in Human Ovarian Cancer Cells}

We found that (-)-asarinin (1) increased the fractionation of the nuclei accumulated at Sub G1 in A2780 and SKOV3 cells, but it failed to induce cell cycle arrest, which is one mechanism of growth inhibition (Figure 2A,B). Therefore, we further explored the molecular mechanism of the cytotoxic activity of (-)-asarinin (1) in human ovarian cancer cells. Dysfunction of apoptosis signaling pathways is associated with cancer development [32]. Therefore, compounds that promote apoptosis in cancer cells are considered as good candidates for anti-cancer chemotherapeutics. To examine whether (-)-asarinin (1)-induced cell death is mediated by the induction of apoptosis, two ovarian cancer cells A2780 and SKOV3 cells were treated with (-)-asarinin (1) and subsequently co-stained with PI and Annexin V-FITC. Treatment with (-)-asarinin (1) increased the percentage of Annexin V-FITC positive/PI negative cells by up to $43 \%$ in A2780 cells and $48 \%$ in SKOV3 cells (Figure 2C,D). These results suggest that the (-)-asarinin (1)-induced cell death is associated with the induction of apoptosis in human ovarian cancer cells.

A
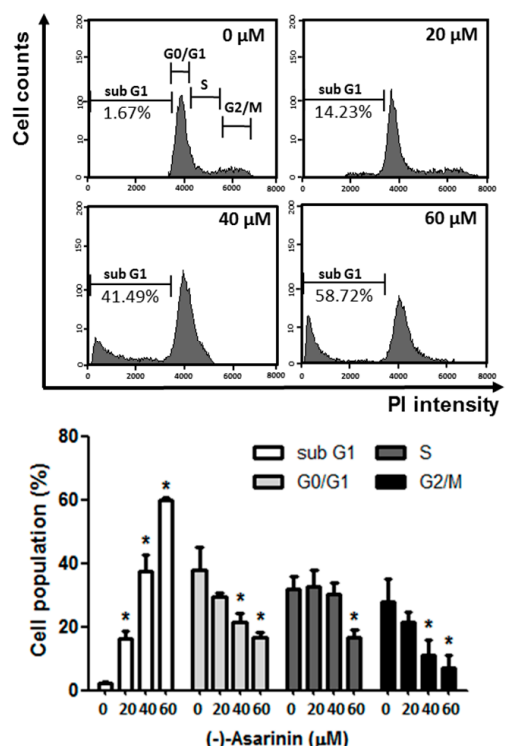

B SKoV3
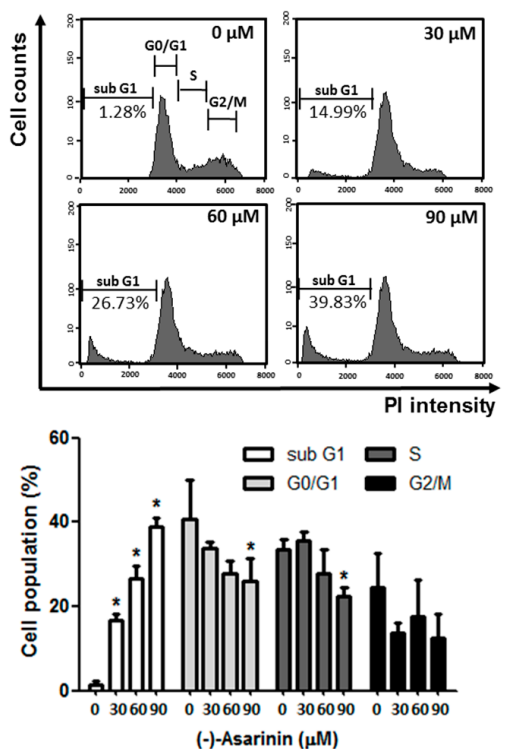

Figure 2. Cont. 
C
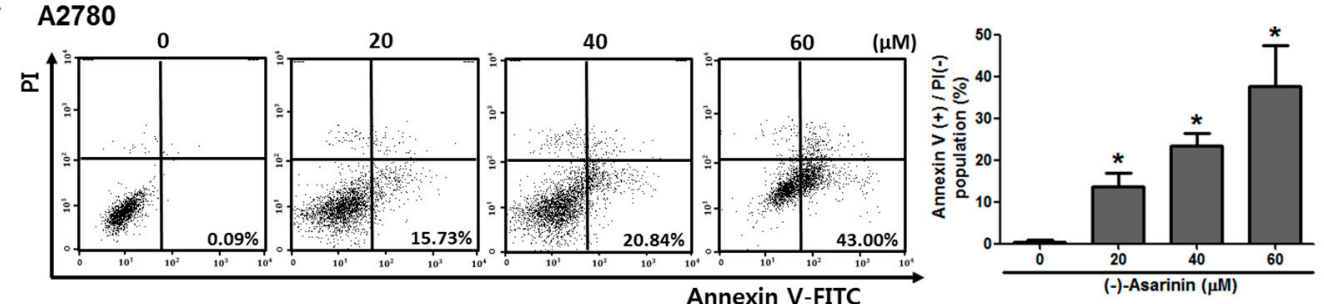

D skov3

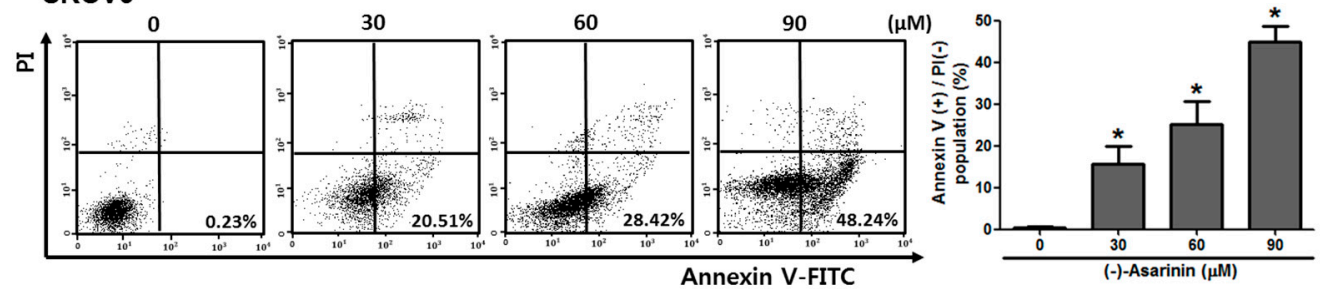

Figure 2. The effect of (-)-asarinin (1) on the cell cycle and apoptosis of human ovarian cancer cells. (A and B) A2780 cells (A) and SKOV3 cells (B) were treated with (-)-asarinin (1) for the indicated concentrations for $48 \mathrm{~h}$. The cells were stained with propidium iodide (PI) according to the protocol as described in method. The cell cycle distribution profiles were measured by flow cytometry. FACS images shown are representative of three independent experiments. Means \pm SD from three independent experiments are graphed from the proportion of cells (\%) in each phase of cell cycle (sub G1, G0/G1, S, and G2/M). Statistical significance was determined by one-way ANOVA. ${ }^{*} p<0.05$ as compared with the untreated group. (C and D) A2780 cells (C) and SKOV3 cells (D) were treated with the indicated concentration of (-)-asarinin (1) for $48 \mathrm{~h}$. Apoptotic cell death analysis was performed using PI/Annexin V-fluorescein isothiocyanate (V-FITC) double staining assay. The data are representative of three independent experiments. Statistical significance was determined by a one-way ANOVA. ${ }^{*} p<0.05$ as compared with the untreated group.

\section{5. (-)-Asarinin (1) Induced Caspase-Dependent Cell Death in Human Ovarian Cancer Cells}

The activation mechanisms that trigger apoptosis are often referred to as the extrinsic and intrinsic pathways [33,34]. The intrinsic pathway (also called the mitochondria-mediated pathway) is activated directly by a variety of intracellular death stimuli. On the other hand, the extrinsic pathway (also called the receptor-mediated pathway) is characterized by the activations of cell-surface death receptors by the binding of extracellular ligands. Both extrinsic and intrinsic apoptotic pathways are highly dependent on the activation of caspases, which play a critical role in the proteolysis of specific targets [35]. Caspase- 8 and caspase- 9 are the initiator caspases for the extrinsic and intrinsic apoptotic pathways, respectively, while the effector caspase caspase-3 can be stimulated by activation of the initiator caspases in both pathways. To identify the mechanisms involved in (-)-asarinin (1)-induced apoptotic cell death, we investigated the activation of an effector caspase, caspase-3 and initiator caspases caspase-8 and caspase-9. (-)-Asarinin (1) markedly stimulated the activation of caspase-3, caspase-8, and caspase-9 in both A2780 and SKOV3 cells (Figure 3). To further confirm the involvement of caspases in (-)-asarinin (1)-induced apoptosis, the effect of caspase inhibitors on (-)-asarinin (1)-induced cell death was investigated. z-DEVD-fmk (a specific caspase-3 inhibitor), z-IETD-fmk (a specific caspase-8 inhibitor), and z-LEHD-fmk (a specific caspase-9 inhibitor) considerably attenuated (-)-asarinin (1)-induced cell death in both A2780 and SKOV3 cells (Figure 4). These results show that (-)-asarinin (1)-induced apoptosis is mediated by the caspase-dependent pathway in human ovarian cancer cells. 

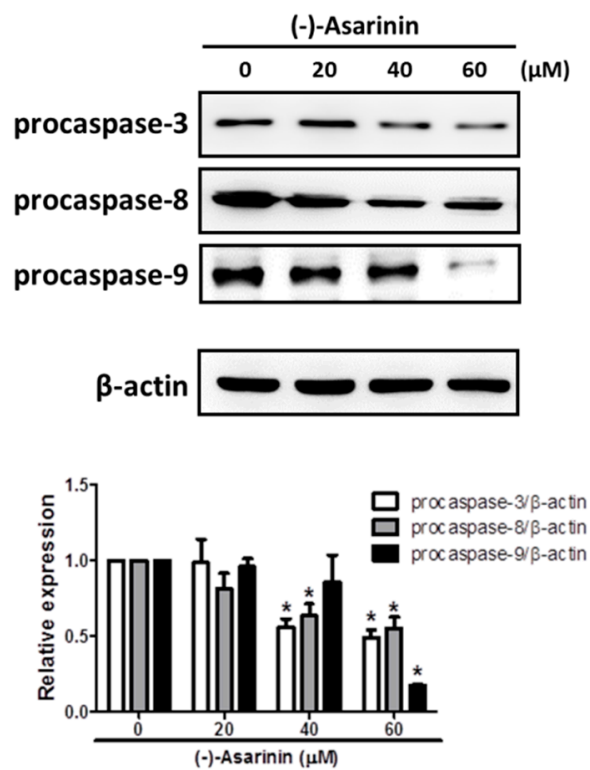
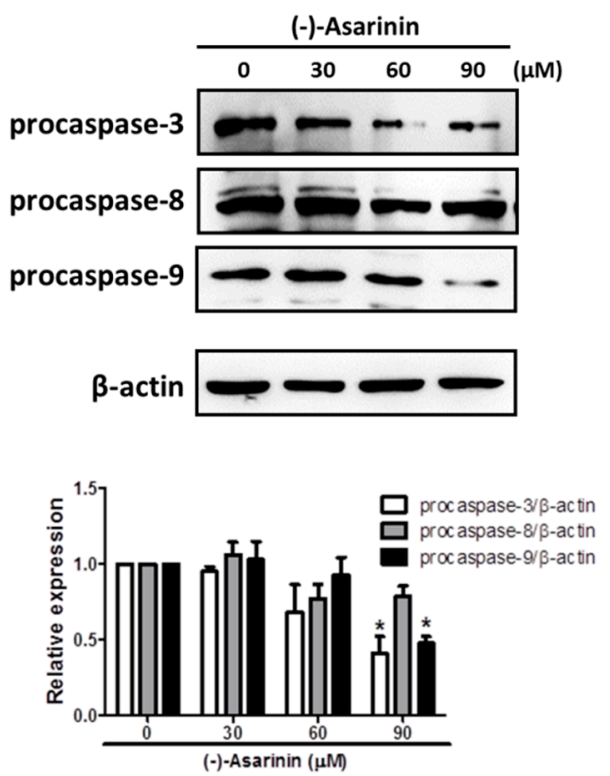

Figure 3. The effect of (-)-asarinin (1) on caspase activation in human ovarian cancer cells. A2780 (A) and SKOV3 (B) cells were treated with the indicated concentration of (-)-asarinin (1) for $48 \mathrm{~h}$. Procaspase-3, -8 , and -9 levels were determined by Western blot assay. $\beta$-Actin was used as an internal control. A representative protein immunoblot of three independent experiments is shown. Data are presented as the means \pm SD of three independent experiments. Statistical significance was determined by one-way ANOVA. ${ }^{*} p<0.05$ as compared with the untreated group.

A

A2780

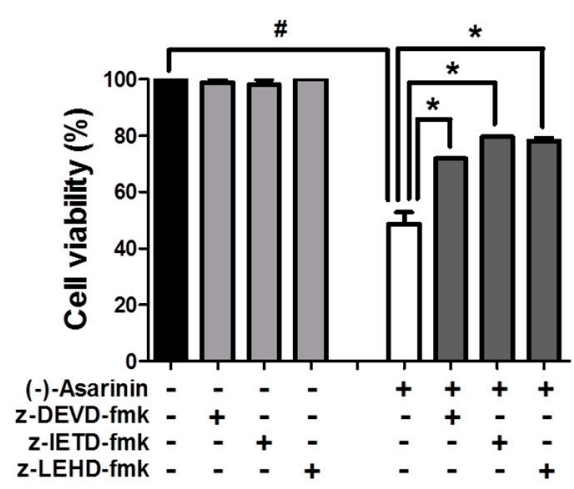

SKOV3

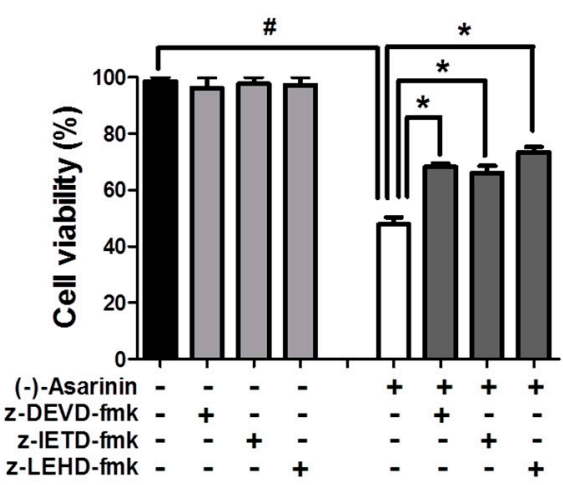

Figure 4. The effect of caspase inhibitors on (-)-asarinin (1)-induced cell death in human ovarian cancer cells. A2780 (A) and SKOV3 (B) cells were pretreated with caspase-3 inhibitor z-DEVD-fmk $(50 \mu \mathrm{M})$, caspase-8 inhibitor z-IETD-fmk $(50 \mu \mathrm{M})$, and caspase-9 inhibitor z-LEHD-fmk $(50 \mu \mathrm{M})$ for $30 \mathrm{~min}$, and then treated with the indicated concentration (A2780; $40 \mu \mathrm{M}$ and SKOV3; $60 \mu \mathrm{M}$ ) of (-)-asarinin (1) for $48 \mathrm{~h}$. A MTT (3-(4,5-dimethylthiazol-2-yl)-2,5-diphenyl-tetrazolium bromide) assay was performed to determine the cell viability after (-)-asarinin (1) treatment. Statistical significance was determined by Student's $t$-test. \# $p<0.05$ as compared with the untreated group and * $p<0.05$ as compared with the (-)-asarinin (1) only-treated group. 


\section{Materials and Methods}

\subsection{General Procedures}

Open column chromatography (CC) was performed with silica gel (70-230 or 230-400 mesh ASTM, Merck, Kenilworth, NJ, USA), Sephadex LH-20 (Amersham Pharmacia Biotech, Piscataway, NJ, USA), reversed-phase silica gel (ODS-A 12 nm S-75 m, YMC Co., Tokyo, Japan), and Redi Sep-C18 (26 g, Teledyne Isco, Lincoln, NE, USA). Thin-layer chromatography (TLC) was performed on Silica gel 60 F254 (Merck) and RP-18 F254S (Merck) plates; compounds were visualized by ultraviolet (UV) light (254 and $365 \mathrm{~nm}$ ) and 20\% $(v / v) \mathrm{H}_{2} \mathrm{SO}_{4}$ reagent (Aldrich, St. Louis, MI, USA). NMR spectra were recorded on a Bruker (Boston, MA, USA) $400 \mathrm{MHz}$ and Varian $500 \mathrm{MHz}$ NMR spectrometer using TMS as an internal standard, and chemical shifts were expressed as $\delta$ values. All solvents used for the chromatographic separations were distilled before use.

\subsection{Plant Meterial}

The roots of Asarum sieboldii Miq. (Aristolochiaceae) were purchased at Miryon Herbal Medicine Co. Gyeonggi-do, Korea, in March, 2013. Plant material was identified by Prof. Dae Sik Jang, one of the authors. A voucher specimen (No. 2013-ASSI01) has been deposited in the Lab of Natural Product Medicine, College of Pharmacy, Kyung Hee University, Republic of Korea.

\subsection{Extraction and Isolation}

The dried roots of $A$. sieboldii (280.4 g) was extracted with $70 \% \mathrm{EtOH}(3.65 \mathrm{~L}$ ) three times at room temperature, each for $6 \mathrm{~h}$. The extract $(40.15 \mathrm{~g})$ was suspended in $\mathrm{H}_{2} \mathrm{O}(350 \mathrm{~mL})$ and successively extracted with EtOAc $(350 \mathrm{~mL} \times 3)$ to yield EtOAc- $(5.73 \mathrm{~g})$ and a water-soluble fraction $(34.92 \mathrm{~g})$, respectively. The EtOAc-soluble fraction $(5.73 \mathrm{~g})$ was chromatographed over silica gel CC (70-230 mesh, $ø 4.7 \times 38.5 \mathrm{~cm})$ as stationary phase with $n$-hexane-EtOAc-MeOH (9:1:0-0:0:1, v/v) as a mobile phase to generate 14 fractions (E1 E14). Fraction E3 $(260.0 \mathrm{mg})$ was subjected to silica gel CC (230-400 mesh, $ø 3.7 \times 22.5 \mathrm{~cm})$ with an $n$-hexane- $\mathrm{CH}_{2} \mathrm{Cl}_{2}$-EtOAc mixture $(7: 3: 0.1, v / v)$ to give compound $5(1.3 \mathrm{mg})$. Compounds 1 (344.4 mg), 2 (20.0 mg), and $3(45.2 \mathrm{mg}$ ) were obtained by recrystallization (in $n$-hexane) from fractions E6 $(274.1 \mathrm{mg})$, E9 $(161.3 \mathrm{mg})$, and E4 $(847.3 \mathrm{mg})$, respectively. Fraction E8 $(740 \mathrm{mg})$ was further subjected to Sephadex LH-20 CC $(\varnothing 3.6 \times 73.5 \mathrm{~cm})$ eluted with $\mathrm{CH}_{2} \mathrm{Cl}_{2}-\mathrm{MeOH}_{\text {mixture }}$ $(1: 1, v / v)$, to produce six subfractions (E8-1 E8-6). Compounds 7 (4.0 mg) and 8 (100.0 mg) were isolated from subfraction E8-2 $(530 \mathrm{mg})$ by reversed-phase CC (YMC gel $75 \mu \mathrm{m}, ø 3.6 \times 23.5 \mathrm{~cm})$ with $\mathrm{MeOH}-\mathrm{H}_{2} \mathrm{O}(4: 1, v / v)$. Fraction E4 $(847 \mathrm{mg})$ was separated using Sephadex LH-20 CC $(\varnothing 3.6 \times 40 \mathrm{~cm})$ eluted with $\mathrm{CHCl}_{3}-\mathrm{MeOH}(1: 1, v / v)$, to give five subfractions (E4-1 E4-5). Compound 6 (487.5 mg) was obtained from subfraction E4-2 by a silica gel CC $(230-400$ mesh, $\varnothing 3.7 \times 22.5 \mathrm{~cm})$. Fraction E5 $(271 \mathrm{mg})$ was fractionated using Sephadex LH-20 CC $(\varnothing 3.6 \times 73.5 \mathrm{~cm})$ with $\mathrm{CH}_{2} \mathrm{Cl}_{2}-\mathrm{MeOH}(1: 1, v / v)$, to generate five subfractions (E5-1 E5-5). Compound $4(29.8 \mathrm{mg})$ was purified from subfraction E5-4 $(70 \mathrm{mg})$ by a flash chromatographic system with a Redi Sep-C18 column $\left(26 \mathrm{~g}, \mathrm{MeOH}-\mathrm{H}_{2} \mathrm{O}=7: 13\right.$ to $3: 2, v / v)$.

\subsection{Cell Culture}

Human ovarian cancer cell lines (A2780 and SKOV3 cells) were obtained from the American Type Culture Collection (ATCC), and immortalized ovarian surface epithelial cell lines (IOSE80PC) were provided by Dr. N. Auersperg (University of British Columbia, Vancouver, British Columbia, Canada) and Dr. A. Godwin (Fox Chase Cancer Center, Philadelphia, PA, USA). Cells were cultured in the Roswell Park Memorial Institute (RPMI) 1640, supplemented with penicillin (100 U/mL), streptomycin sulfate $(100 \mu \mathrm{g} / \mathrm{mL})$, and 5\% fetal bovine serum (FBS) (Life Technologies, Inc., Grand Island, NY, USA) in a humidified atmosphere of $5 \% \mathrm{CO}_{2}-95 \%$ air at $37{ }^{\circ} \mathrm{C}$. 


\subsection{MTT Assay}

A MTT assay was performed to evaluate the cell viability. The MTT was obtained from Molecular Probes Inc. (Eugene, OR, USA). Briefly, the cells $\left(1.0 \times 10^{5} /\right.$ well $)$ were seeded in a 96-well plate and incubated for $24 \mathrm{~h}$. The cells were treated with extracts $(0.125-200 \mu \mathrm{g} / \mathrm{mL})$ and compounds $(0.125-200 \mu \mathrm{M})$ and incubated for $48 \mathrm{~h}$. MTT solution was added into each well (final concentration; $0.5 \mathrm{mg} / \mathrm{mL}$ ) and the plates were incubated for an additional $4 \mathrm{~h}$. The medium was removed and $50 \mu \mathrm{L}$ of dimethyl sulfoxide (DMSO) was added. The optical density was measured at $540 \mathrm{~nm}$ using a microplate spectrophotometer (SpectraMax; Molecular Devices, Sunnyvale, CA, USA). To investigate the involvement of caspases in asarinin (1)-induced cell death, a MTT assay was also performed using caspase inhibitors. The cells were pretreated with caspase inhibitors $(50 \mu \mathrm{M})$ for $30 \mathrm{~min}$, and treated with (-)-asarinin (1) (A2780, $40 \mu \mathrm{M}$; and SKOV3, $60 \mu \mathrm{M}$ ) for $48 \mathrm{~h}$. Caspase-3 inhibitor z-DEVD-fmk, caspase- 8 inhibitor z-IETD-fmk, and caspase-9 inhibitor z-LEHD-fmk were purchased from Calbiochem (Bad Soden, Germany).

\subsection{Cell Cycle Analysis}

The cells were treated with (-)-asarinin (1) and incubated for $48 \mathrm{~h}$. At the time of collection, the cells were harvested and washed twice with ice-cold phosphate buffered saline (PBS). The cells were fixed and permeabilized with $70 \%$ ice-cold ethanol at $-20^{\circ} \mathrm{C}$ for $4 \mathrm{~h}$. The cells were washed once with PBS and resuspended in a staining solution containing propidium iodide $(50 \mu \mathrm{g} / \mathrm{mL})$ and RNase A $(5 \mathrm{mg} / \mathrm{mL})$. The cell suspensions were incubated for $30 \mathrm{~min}$ at room temperature in a dark place. After $30 \mathrm{~min}$ the suspensions were analyzed by fluorescence-activated cell sorting (FACS) cater-plus flow cytometry (guava easy cyte ${ }^{\mathrm{TM}}$, Merk Millipore, Darmstadt, Germany) using 5000 cells per group.

\subsection{Annexin V-FITC/PI Double Staining}

Annexin V- FITC was obtained from BD Biosciences (San Jose, CA, USA). The cells were treated with (-)-asarinin (1) and incubated for $48 \mathrm{~h}$. The cells were rinsed twice with ice-cold PBS and suspended with $100 \mu \mathrm{L}$ of binding buffer (10 mM HEPES/ NaOH, $140 \mathrm{mM} \mathrm{Nacl}, 2.5 \mathrm{mM} \mathrm{CaCl}_{2}$, PH 7.4). A total of $5 \mu \mathrm{L}$ of FITC-conjugated annexin V and $5 \mu \mathrm{L}$ of PI $(50 \mathrm{mg} / \mathrm{mL})$ were added into the cell suspension, and the mixture was incubated in a dark place at room temperature for $15 \mathrm{~min}$. The cells were analyzed using FACS cater-plus flow cytometry (guava easy cyte ${ }^{\mathrm{TM}}$ ); at least 10,000 cells per each group were counted.

\subsection{Western Blot Assay}

The cells were treated with (-)-asarinin (1) and incubated for $48 \mathrm{~h}$. The cells were rinsed twice with ice-cold PBS and lysed with protein lysis buffer (Intron Biotechnology, Seoul, Korea) containing protease inhibitors ( $0.5 \mathrm{mM}$ PMSF and $5 \mu \mathrm{g} / \mathrm{mL}$ aprotinin). The lysates were mixed with $5 \mathrm{X}$ sodium dodecyl sulfate (SDS) sample buffer and boiled for $5 \mathrm{~min}$ for denaturation. Total protein was run on 10-12\% SDS-PAGE gels and electrotransferred onto a polyvinylidene difluoride (PVDF) membrane. The membrane was immunoblotted using specific primary antibodies overnight at $4{ }^{\circ} \mathrm{C}$ following blocking with $5 \%$ non-fat dry milk for $30 \mathrm{~min}-1 \mathrm{~h}$. After washing, the membrane was incubated with horseradish peroxidase-conjugated secondary antibody (1:1000-2000) at room temperature for $1-2 \mathrm{~h}$. After washing, immunepositive bands were visualized using an ECL chemiluminescent system and analyzed by Image Quant LAS-4000 (Fujifilm Life science, Tokyo, Japan). Anti-caspase-3 and b-actin antibodies were obtained from Santa Cruz Biotechnology (Santa Cruz, CA, USA). Caspase-9 antibody was purchased from Cell Signaling (Beverly, MA, USA). Caspase-8 antibody was obtained from BD Biosciences (San Jose, CA, USA). 


\subsection{Statistical Analysis}

One-way ANOVA and Student's $t$-test were performed to determine statistically significant differences. $p$-values of less than 0.05 were regarded as statistically significant.

\section{Conclusions}

Fractionation of the active EtOAc-soluble fraction from the 70\% $\mathrm{EtOH}$ extract of the roots of A. sieboldii resulted in the isolation and identification of two tetrahydrofurofurano lignans (1 and $\mathbf{2})$, four phenylpropanoids (3-6), and two alkamides (7 and 8). Of the isolates, (-)-asarinin (1) exhibited the most potent cytotoxicity against two human ovarian cancer cells, A2780 and SKOV3, while it did not affect cell viability of normal human ovarian epithelial cells IOSE80PC. Treatment with (-)-asarinin (1) significantly induced apoptotic cell death in both A2780 and SKOV3 cells. We further demonstrated that (-)-asarinin (1) stimulated the activation of caspase-3, caspase-8, and caspase-9, and caspase inhibitors significantly reversed (-)-asarinin (1)-induced cell death in human ovarian cancer cells. Taken together, these results suggest that (-)-asarinin (1), a major component of the roots of $A$. sieboldii, induces apoptotic cell death specifically against cancer cells via the caspase-dependent pathway.

Author Contributions: D.S.J. and J.-H.C. conceived and designed the experiments; M.J., H.M.K., and J.S.L. performed the experiments and analyzed the data; H.M.K. and M.J. wrote the paper.

Funding: This research was funded by a grant from the Bio-Synergy Research Project (NRF-2015M3A9C4070483) of the Ministry of Science, ICT and Future Planning through the National Research Foundation of Korea (NRF), and by Basic Science Research Program through the NRF funded by the Ministry of Education (NRF-2016R1D1A1B03930222).

Conflicts of Interest: The authors declare no conflict of interest.

\section{References}

1. Drew, A.K.; Whyte, I.M.; Bensoussan, A.; Dawson, A.H.; Zhu, X.; Myers, S.P. Chinese herbal medicine toxicology database: Monograph on Herba Asari, "Xi Xin". J. Toxicol. Clin. Toxicol. 2002, 40, 169-172. [CrossRef] [PubMed]

2. Ramalingam, M.; Kim, S.J. Phytochemical, toxicological and pharmacological studies of Asiasari Radix et Rhizoma: A Review. Trop. J. Pharm. Res. 2015, 14, 545-554. [CrossRef]

3. Kim, H.M.; Moon, Y.S. Asiasari radix inhibits immunoglobulin E production on experimental models in vitro and in vivo. Immunopharm. Immunot. 1999, 21, 469-481. [CrossRef] [PubMed]

4. Kosuge, T.; Yokota, M.; Nukaya, H.; Gotoh, Y.; Nagasawa, M. Studies on antitussive principles of Asiasari radix. Chem. Pharm. Bull. 1978, 26, 2284-2285. [CrossRef]

5. Han, A.R.; Kim, H.J.; Shin, M.; Hong, M.; Kim, Y.S.; Bae, H. Constituents of Asarum sieboldii with inhibitory activity on lipopolysaccharide (LPS)-induced NO production in BV-2 microglial cells. Chem. Biodivers. 2008, 5, 346-351. [CrossRef] [PubMed]

6. Kim, S.J.; Zhang, C.G.; Lim, J.T. Mechanism of antinociceptive effects of Asarum sieboldii Miq. Radix: Potential role of bradykinin, histamine and opioid receptor-mediated pathways. J. Ethnopharmacol. 2003, 88, 5-9. [CrossRef]

7. Lee, J.Y.; Moon, S.S.; Hwang, B.K. Isolation and antifungal activity of kakuol, a propiophenone derivative from Asarum sieboldii rhizome. Pest. Manag. Sci. 2005, 61, 821-825. [CrossRef] [PubMed]

8. Yu, H.H.; Seo, S.J.; Hur, J.M.; Lee, H.S.; Lee, Y.E.; You, Y.O. Asarum sieboldii extracts attenuate growth, acid production, adhesion, and water-insoluble glucan synthesis of Streptococcus mutans. J. Med. Food 2006, 9 , 505-509. [CrossRef] [PubMed]

9. Han, Y.; Kim, S.J. Memory enhancing actions of Asiasari radix extracts via activation of insulin receptor and extracellular signal regulated kinase (ERK) I/II in rat hippocampus. Brain Res. 2003, 974, 193-201. [CrossRef]

10. Oh, S.M.; Kim, J.; Lee, J.; Yi, J.M.; Oh, D.S.; Bang, O.S.; Kim, N.S. Anticancer potential of an ethanol extract of Asiasari radix against HCT-116 human colon cancer cells in vitro. Oncol. Lett. 2013, 5, 305-310. [CrossRef] [PubMed] 
11. Park, J.D.; Baek, N.I.; Lee, Y.H.; Kim, S.I. Isolation of a cytotoxic agent from Asiasari Radix. Arch. Pharm. Res. 1996, 19, 559-561. [CrossRef]

12. Hashimoto, K.; Katsuhara, T.; Itoh, H.; Ikeya, Y.; Okada, M.; Mitsuhashi, H. Monoterpenes from asiasari radix from Asiasarum sp. Phytochemistry 1990, 29, 3571-3574. [CrossRef]

13. Hashimoto, K.; Katsuhara, T.; Niitsu, K.; Ikeya, Y.; Hayashi, K.; Maruno, M.; Fujita, T. Enantioexcess monoterpenes from roots of Asiasarum sieboldi. Phytochemistry 1994, 35, 969-973. [CrossRef]

14. Wagner, H.; Bauer, R.; Melchart, D.; Xiao, P.G.; Staudinger, A. Radix et Rhizoma Asari-Xixin. In Chromatographic Fingerprint Analysis of Herbal Medicines; Springer: Vienna, Austria, 2011; pp. 45-57, ISBN 978-3-319-09298-0.

15. Lo, C.F.; Chen, C.M. Determination of higenamine in plasma and urine by high-performance liquid chromatography with electrochemical detection. J. Chromatogr. B 1994, 655, 33-39. [CrossRef]

16. Masaki, N.; Iizuka, H.; Yokota, M.; Ochiai, A. Crystal structure of higenamine [1, 2, 3, 4-tetrahydro-1-(4-hydroxybenzyl) isoquinoline-6, 7-diol] hydrobromide. J. Chem. Soc. Perkin 1 1977, 7, 717-719. [CrossRef]

17. Takara, K.; Horibe, S.; Obata, Y.; Yoshikawa, E.; Ohnishi, N.; Yokoyama, T. Effects of 19 herbal extracts on the sensitivity to paclitaxel or 5-fluorouracil in HeLa cells. Biol. Pharm. Bull. 2005, 28, 138-142. [CrossRef] [PubMed]

18. Jeong, M.; Kim, H.M.; Kim, H.J.; Choi, J.H.; Jang, D.S. Kudsuphilactone B, a nortriterpenoid isolated from Schisandra chinensis fruit, induces caspase-dependent apoptosis in human ovarian cancer A2780 cells. Arch. Pharm. Res. 2017, 40, 500-508. [CrossRef] [PubMed]

19. Choi, E.H.; Choi, J.Y.; Lee, J.G.; Oh, J.S.; Kim, D.C.; Lee, H.S.; Son, J.K.; Ryang, S.A.; Kim, J.A.; Lee, S.H. Isolation of melanin biosynthesis inhibitory compounds from the roots of Asarum sieboldii. Korean J. Pharmacogn. 2007, 38, 394-399.

20. Roy, S.C.; Rana, K.K.; Guin, C. Short and stereoselective total synthesis of furano lignans (+/-)-dihydrosesamin, (+/-)-lariciresinol dimethyl ether, (+/-)-acuminatin methyl ether, $(+/-)$-sanshodiol methyl ether, (+/-)-lariciresinol, (+/-)-acuminatin, and (+/-)-lariciresinol monomethyl ether and furofuran lignans (+/-)-sesamin, (+/-)-eudesmin, (+/-)-piperitol methyl ether, (+/-)-pinoresinol, (+/-)-piperitol, and (+/-)-pinoresinol monomethyl ether by radical cyclization of epoxides using a transition-metal radical source. J. Org. Chem. 2002, 67, 3242-3248. [CrossRef] [PubMed]

21. Musso, L.; Dallavalle, S.; Merlini, L.; Farina, G. Synthesis and Antifungal Activity of 2-Hydroxy-4, 5-methylenedioxyaryl Ketones as Analogues of Kakuol. Chem. Biodivers. 2010, 7, 887-897. [CrossRef] [PubMed]

22. Hofer, O.; Greger, H.; Robien, W.; Werner, A. ${ }^{13} \mathrm{C}$ NMR and ${ }^{1} \mathrm{H}$ lanthanide induced shifts of naturally occurring alkamides with cyclic amide moieties-amides from achilleafalcata. Tetrahedron 1986, 42, 2707-2716. [CrossRef]

23. Bizzo, H.R.; Lopes, D.; Abdala, R.V.; Pimentel, F.A.; de Souza, J.A.; Pereira, M.V.; Bergter, L.; Guimarães, E.F. Sarisan from leaves of Piper affinis hispidinervum C. DC (long pepper). Flavour Fragr. J. 2001, 16, 113-115. [CrossRef]

24. Lopes-Lutz, D.; Mudge, E.; Ippolito, R.; Brown, P.; Schieber, A. Purification of alkylamides from Echinacea angustifolia (DC.) Hell. roots by high-speed countercurrent chromatography. J. Agric. Food Chem. 2010, 59, 491-494. [CrossRef] [PubMed]

25. Truan, J.S.; Chen, J.M.; Thompson, L.U. Comparative effects of sesame seed lignan and flaxseed lignan in reducing the growth of human breast tumors (MCF-7) at high levels of circulating estrogen in athymic mice. Nutr. Cancer 2012, 64, 65-71. [CrossRef] [PubMed]

26. Hirose, N.; Doi, F.; Ueki, T.; Akazawa, K.; Chijiiwa, K.; Sugano, M.; Akimoto, K.; Shimizu, S.; Yamada, H. Suppressive effect of sesamin against 7,12-dimethylbenz[a]-anthracene induced rat mammary carcinogenesis. Anticancer Res. 1992, 12, 1259-1265. [PubMed]

27. Deng, P.; Wang, C.; Chen, L.; Wang, C.; Du, Y.; Yan, X.; Chen, M.; Yang, G.; He, G. Sesamin induces cell cycle arrest and apoptosis through the inhibition of signal transducer and activator of transcription 3 signalling in human hepatocellular carcinoma cell line HepG2. Biol. Pharm. Bull. 2013, 36, 1540-1548. [CrossRef] [PubMed] 
28. Hibasami, H.; Fujikawa, T.; Takeda, H.; Nishibe, S.; Satoh, T.; Fujisawa, T.; Nakashima, K. Induction of apoptosis by Acanthopanax senticosus HARMS and its component, sesamin in human stomach cancer KATO III cells. Oncol. Rep. 2000, 7, 1213-1219. [CrossRef] [PubMed]

29. Takasaki, M.; Konoshima, T.; Yasuda, I.; Hamano, T.; Tokuda, H. Inhibitory effects of shouseiryu-to on two-stage carcinogenesis. II. Anti-tumor-promoting activities of lignans from Asiasarum heterotropoides var mandshuricum. Biol. Pharm. Bull. 1997, 20, 776-780. [CrossRef] [PubMed]

30. Konoshima, T.; Takasaki, M. Anti-tumor-promoting activities (cancer chemopreventive activities) of natural products. Stud. Nat. Prod. Chem. 2000, 24, 215-267. [CrossRef]

31. Ju, Y.; Still, C.C.; Sacalis, J.N.; Li, J.; Ho, C.T. Cytotoxic coumarins and ligmans from extracts of the northern prickly ash (Zanthoxylum americanum). Phytother. Res. 2001, 15, 441-443. [CrossRef] [PubMed]

32. Elmore, S. Apoptosis: A Review of Programmed Cell Death. Toxicol Pathol. 2007, 35, 495-516. [CrossRef] [PubMed]

33. Wang, C.; Youle, R.J. The Role of Mitochondria in Apoptosis. Annu Rev. Genet. 2009, 42, 95-118. [CrossRef] [PubMed]

34. Kantari, C.; Walczak, H. Caspase-8 and Bid: Caught in the act between death receptors and mitochondria. Biochim. Biophys. Acta 2011, 1813, 558-563. [CrossRef] [PubMed]

35. Creagh, E.M. Caspase crosstalk: Integration of apoptotic and innate immune signalling pathways. Trends Immunol. 2014, 35, 631-640. [CrossRef] [PubMed]

Sample Availability: Not available.

(C) 2018 by the authors. Licensee MDPI, Basel, Switzerland. This article is an open access article distributed under the terms and conditions of the Creative Commons Attribution (CC BY) license (http://creativecommons.org/licenses/by/4.0/). 